\title{
EFFICACY OF NATIVE ENTOMOPATHOGENIC FUNGI ISOLATES AND BIOLOGICAL STUDIES ON SPODOPTERA LITTORALIS (BOISD.)
}

\author{
SAHAR S. ALI and MARWA M.A.EL-SABAGH
}

Plant Protection Research Institute, ARC, Dokki, Giza, Egypt

(Manuscript received 29 September 2015)

\begin{abstract}
$\mathrm{V}$ irulence of three local isolates of entomopathogenic fungi ; Beauveria bassiana (AUMC 9896), Lecanicillium antillanum (=Verticillium antillanum) (AUMC 9905) and Paecilomyces lilacinus (AUMC 9897), as well as, Metarhizium anisopliae which isolated in Bio-insectcide Production Unit, Plant Protection Research Institute were evaluated against Spodoptera littoralis larvae under laboratory conditions. Five concentrations of spores suspension from each of the four fungal isolates $\left(1 \times 10^{5}, 1 \times 10^{6}\right.$, $1 \times 10^{7}, 1 \times 10^{8}$ and $1 \times 10^{9}$ conidia / ml) were used against newly hatched larvae of $S$. littoralis pest. The results showed that the percentage mortality of the larvae increased with increasing concentrations of tested pathogens. The median time of mortality decreased as the spores concentration increased. Also, the isolate $B$. bassiana was the most effective against $S$. littoralis larvae at different tested concentrations. $B$. bassiana at high concentration of $1.0 \times 10^{9}$ revealed $88.5 \%$ mortality within mean time to larval mortality $5.1 \pm 1.9$ days. In biological Studies all tested fungi decreased the mean larval duration about 24 hours than untreated larvae and decreased of pupation. $L$. antillanum recorded the least Pupation percentage $45 \%$. All tested fungi showed significantly shortening in the mean adult longevity for both males and females. All tested fungi significantly decreased the mean number of eggs laid and hatched /female.
\end{abstract}

\section{INTRODUCTION}

The Egyptian cotton leafworm, $S$. littoralis is one of the most destructive polyphagous insect, not only to cotton, but also to other field crops and vegetables in Egypt (Kandil et al., 2003). Due to extensive using of insecticide groups, many populations of $S$. littoralis have acquired resistance towards most of them (Alford, 2000). The problems and hazards that have arisen as a result of using conventional insecticides were incentives for the search of alternative control agents. Microbial control agents are a primary means of biological control for insect pests. The use of microbial control agents is targeted for a particular pest species. The entomopathogens that have most been used in biological control include representatives of bacteria, fungi, viruses, nematodes, protozoa and insect growth regulator (Dent, 2000). 
The entomopathogenic fungi are the promising agents that are used against insect pests for several decades. These organisms include taxa of several fungal groups like Hypocreales of Ascomycota that $B$. bassiana and M. anisopliae are the two most recognized species (Vincent et al., 2007). B. bassiana and M. anisopliae grow naturally throughout the world and acts as parasites of many arthropod species causing white and green muscardine diseases due to the color of their spores. Besides entomopathogenic fungi cause natural mortality on insects, these agents are environmentally safe, so there is a worldwide interest of their using and improvement for biological control of insects (Vincent et al., 2007). Aim of the present investigation is to evaluate the virulence of four entomopathogenic fungi against $S$. littoralis (Boisd.).

\section{MATERIALS AND METHODS}

\section{A-Fungus culture:}

Different isolates of the entomopathogenic fungi; B. bassiana (AUMC 9896), $L$. antillanum ( $=$ V. antillanum) (AUMC 9905), P. lilacinus (AUMC9897) and M. anisopliae were isolated in Bio-insectcide Production Unit, Plant Protection Research Institute and were identified in Mycological Center, Faculty of Science, Assiut University. Sahar and Moharram (2014), these entomopathogenic fungi were cultured on potato dextrose agar medium, incubated at $27 \pm 1^{\circ} \mathrm{C}$ for 15 days. The conidia were harvested by scraping the surface of 14-15 days old culture gently with inoculation needle. The conidia were suspended in distilled water containing $0.1 \%$ Tween- 80 . The mixture was stirred with a magnetic shaker for ten minutes.

\section{B-Rearing of the S. littoralis (Boisd):}

Egg masses of a sensitive strain of the cotton leaf worm, S. littoralis (Boisd.) were incubated under laboratory condition at $27 \pm 2^{\circ} \mathrm{C}, 60 \pm 5 \% \mathrm{RH}$ and $8: 16 \mathrm{LD}$ photoperiod. The original insect culture was obtained from the Research Division of the Cotton Leaf worm, Plant Protection Research Institute. Newly hatched larvae were transferred to clean glass jars covered with muslin cloth held in position with rubber bands. They were fed on castor bean leaves, Ricinus communis (L.) and examined daily. Upon pupation, pupae were collected; sexed and emerged moths were placed in pairs in breeding glass jars, supplied with leaves of tafla, Nerium oleander (L.) as an oviposition site. Each jar was provided with cotton piece soaked in $10 \%$ honey solution and placed in small plastic cup for moths feeding. The honey solution was renewed daily to avoid fermentation and growth of microorganisms. 


\section{C-Bioassay:}

Virulence of the fungi isolates against newly hatched $S$. littoralis larvae was performed by testing five concentrations of spores suspension from each of the four fungal isolates $\left(1 \times 10^{5}, 1 \times 10^{6}, 1 \times 10^{7}, 1 \times 10^{8}\right.$ and $1 \times 10^{9}$ conidia / replicate $)$. Fresh of castor leaves (2 leaves) were sprayed with each concentration and distilled water as control. After air drying, the treated leaves were transferred into a plastic container (15 cm diameter) were contaminated with each concentration and provided with 20 larvae each replicate ( 5 replicate); then were covered with muslin cloth for aeration (Hicks et al., 2001). Larvae were maintained in an incubator at $27.0 \pm 1.0^{\circ} \mathrm{C}$ with adjusted relative humidity of $70.0 \pm 5.0 \% \mathrm{RH}$. Dead larvae were counted daily and mortality was calculated. Also, the median lethal time $\left(\mathrm{LT}_{50}\right)$ of mortality was calculated. The percentage reduction in mortality of larvae was calculated and corrected according to Abbott's formula (1925). The experiment was replicated 4 times (20 larvae / replicate). (El-Hawary and Abd El-Salam, 2009).

\section{D-Biological studies:}

Newly hatched larvae from the maintained insect colony were collected and offered daily with castor bean leaves that treated with $1 \times 10^{7}$ conidia / $\mathrm{ml}$ as the recommended dose (Lin et al., 2007). Treated instars larvae were examined daily in order to study the following parameters: larval and pupal duration of each instar and percentage of pupation. Pupae were sexed and then placed in 3 pairs in the glass jars of the following combinations: treated male $x$ treated female and for a control untreated male $x$ untreated female. Subsequently, percentage of adult emergence, longevity of moths and the fecundity and fertility of eggs/female, were determined.

\section{RESULTS AND DISCUSSION}

\section{A-Virulence of fungi isolates by bioassay:}

The data in Table (1) indicate that the percentage mortality of the larvae was increased with increasing concentrations of tested pathogens. However, median lethal time $\left(L T_{50}\right)$ decreased as the spores concentration increased. Also, the isolate $B$. bassiana was the most effective against $S$. littoralis larvae. $B$. bassiana at high concentration of $1.0 \times 10^{9}$ achieved $88.5 \%$ mortality within mean time to larval mortality $5.1 \pm 1.9$ days, flowed by the concentrations $1.0 \times 10^{8}, 1.0 \times 10^{7}, 1.0 \times 10^{6}$ and $1.0 \times 10^{5}$ which recorded $66.5 \%, 59.5 \%, 47.5 \%$ and $45.0 \%$ mortality within $5.6 \pm 1.6,5.8 \pm 1.1,9.2 \pm 1.0$ and $12.1 \pm 1.2$ days, respectively (Table 1 ).

While $L$. antillanum at the high concentration $1.0 \times 10^{9}$ resulted in $62.5 \%$ mortality within $7.1 \pm 1.4$ days. Followed by the concentrations $1.0 \times 10^{8}, 1.0 \times 10^{7}, 1.0$ 
$x 10^{6}$ and $1.0 \times 10^{5}$ achieved $55.5 \%, 41.0 \%, 22.0 \%$ and $21.5 \%$ mortality within $9.3 \pm$ $1.6,10.3 \pm 1.0,10.5 \pm 2.1$ and $11.0 \pm 1.6$ days, respectively (Table 1 ).

Also, in concentration $1.0 \times 10^{9}$, of $P$. lilacinus gave $67.5 \%$ mortality within $6.6 \pm 2.1$ days. Wherer as the concentrations $1.0 \times 10^{8}, 1.0 \times 10^{7}, 1.0 \times 10^{6}$ and $1.0 \times 10^{5}$ achieved $56.5 \%, 45.5 \%$, and $35.0 \%$ and $33.5 \%$ mortality within $7.1 \pm 2.2,7.5 \pm 1.5$, $9.0 \pm 1.2$ and $10.3 \pm 1.1$ days, respectively. Finally, $M$. anisopliae at the high concentration $1.0 \times 10^{9}$ achieved $60.5 \%$ mortality within $6.2 \pm 2.3$ days. Followed the concentrations $1.0 \times 10^{8}, 1.0 \times 10^{7}, 1.0 \times 10^{6}$ and $1.0 \times 10^{5}$ resulted in $50.5 \%, 31.5 \%$, $25.5 \%$ and $19.5 \%$ mortality within $7.5 \pm 1.9,8.8 \pm 2.6$, and $10.1 \pm 2.8$ and $11.8 \pm 1.8$ days, respectevly.

Results are agree with those obtained by El-Hawary and Abd El-Salam (2009) who found that percentage mortalities of treated third instar larvae of $S$. littoralis with (i.e. Bio- Power, B. bassiana ) was87.5\%. However, Hassani et al., (2000) stated that $P$. fumosoroseus is highly virulent against these three important cotton pests ( $S$. littoralis Helicoverpa armigera and Aphis gossypii).

Quesada-Moraga and Vey, (2004) found that injection of Bassiacridin (B. bassiana metabolite ) at a dose of $2.8 \mu \mathrm{g} / \mathrm{g}$ to fourth instar nymphs of locusts Locusta migratoria, Schistocerca gregaria and Dociostaurus maroccanus, and to fifth instar larvae of the lepidopterans Galleria mellonella and S. littoralis, and of the coleopteran Tenebrio molitor. Bassiacridin was not toxic to $S$. littoralis and $T$. molitor, whereas it was slightly toxic to $G$. mellonella causing $16.6 \%$ corrected mortality. In contrast, it was equally toxic to the migratory locusts $L$. migratoria and to the desert locust $S$. gregaria, with mortality rates of 42.5 and $38.3 \%$ respectively, and slightly more toxic to the Moroccan locust $D$. maroccanus, causing $49.2 \%$ mortality.

\section{B-Biological Studies:}

The obtained results in Table (2) clarified the effect of the tested fungi on the mean larval duration, pupation, and pupal duration. Treatment of the newly hatched $S$. littoralis instars larvae with $1 \times 10^{7}$ conidia / $\mathrm{ml}$ of fungi decreased the mean larval duration about 0.7-1.7 day than untreated larvae. And this was in agreement with Abd El-Kareem, (2012) who found that the treatment of $2^{\text {nd }}$ and $4^{\text {th }}$ instars larvae of $S$. littoralis with Bioranza has reduced the mean larval duration while that treated with Protecto, Viruset, and Profect has prolonged the duration of the treated instars larvae. Meanwhile, the pupation were decrease in all isolates and the pupal stage of instar larvae treated with $B$. bassiana, L. antillanum, P. lilacinus and M. anisopliae were decreased (13.2, 12.3, 13.6 and 11.3 days) respectively, than untreated larvae (14.6 days). 
Instars larvae treated with $L$. antillanum have recorded the least Pupation percentage (45\%); than that recorded with treated larvae with $B$. bassiana, $P$ lilacinus and $M$. anisopliae ( $48.8 \% 48.3 \%$ and $46.5 \%$ ) respectively. These results were agreed with those of Hafez et al. (1997) who treated Phthorimae aoperculella larvae with Beauveria bassiana.

Observed reduction in the adult emergence was recorded in all treatments. Also, all tested fungi showed significantly shortening in the mean adult longevity for both males and females (Table 3). Some of emerged adults were also malformed with reduced wings or reduced body size. They were unable to fly and died without mating. It has been investigated that pupae treated with fungal pathogens often result reduction in the adult emergence (Ekesi et al., 2002), increase in pupal duration and malformed adults (Hafez et al., 1997). Our findings are contradictory to findings of $S$. littoralis.

That was in concides with Abd El-Kareem (2012) who noticed decrease in the percentage of adult emergenceand mean adult longevity of treated larvae of $S$. littoralis with Bioranza. Dubois et al. (2004) studied the effect of two commercially products of $B$. bassiana and $B$. brongniartii, a reduction in the adult longevity of the beetle Anoplophora glabripennis was found, same findings recorded with Abd El-Kareem (2007) who treated larvae of Ostrinia nubilalis with A. flavus.

Table (4) showed the latent effect of the treated $S$. littoralis with $1 \times 10^{7}$ conidia / replicate of tested fungi on the mean number of laid and hatched eggs/female. All tested fungi significantly decreased the mean number of eggs laid/female. M. anisopliae was the most effective fungus, followed by $B$. bassiana, $L$. antillanum and $P$. lilacinus On the other hand, significantly reduction in the mean number of hatched eggs/female was observed when treated instar larvae with recommended dose of all tested (Table 4). That was in agreement with Noma and Strickler (2000) who investigated the effects of B. bassiana infection on ovipositional behavior of Lygus hesperus caused.

The decrease in reproductive potential of $S$. littoralis and decrease egg formation and number of deposited eggs in treated moth with fungi was explained by Santiago-Alvarez and Osuna (1988) who found that males of S. littolaris infected with bioagents are not able to mate with un treated females and produced the normal egg percentage like un treated male in addition to reduced the percentage of the egg hatchability also. Aldeebis et al., 1993 clarified that was due to inability of the sperms to transfer to the females during copulation, which was suggested also by Ismail (1980). Same findings was discussed by (Hassan, 2004; Hatem, 2006; Abdel-Aziz, 2007 and ElKhateeb and El-Sabagh, 2008). 
From the present studies is could be concluded that the isolate $B$. bassiana was more potent against $S$. littoralis and that all biological stages of $S$. lituralis were affected to varying degrees to infection by the entomopathogenic fungi isolates.

Table 1. Corrected accumulative mortality percentages and mean time to larval mortality of the larval stage of $S$. littolaris treated with different concentrations of entomopathogenic fungi isolates.

\begin{tabular}{|c|c|c|c|c|c|c|c|c|}
\hline \multirow{3}{*}{${ }^{*}$ Conc . } & \multicolumn{7}{|c|}{ Tested isolate } & \\
\hline & \multicolumn{2}{|c|}{ B. bassiana } & \multicolumn{2}{|c|}{ L. antillanum } & \multicolumn{2}{|c|}{ P. lilacinus } & \multicolumn{2}{|c|}{ M. anisopliae } \\
\hline & $\begin{array}{c}\text { mortality } \\
\% \\
\end{array}$ & $\mathrm{LT}_{50}$ & $\begin{array}{c}\text { mortality } \\
\% \\
\end{array}$ & $\mathrm{LT}_{50}$ & $\begin{array}{c}\text { mortality } \\
\% \\
\end{array}$ & $\mathrm{LT}_{50}$ & $\begin{array}{c}\text { mortality } \\
\% \\
\end{array}$ & $\mathrm{LT}_{50}$ \\
\hline $1 \times 10^{5}$ & 45.0 & $12.1 \pm 1.2$ & 21.5 & $11.0 \pm 1.6$ & 33.5 & $10.3 \pm 1.1$ & 19.5 & $\begin{array}{c}11.8 \pm \\
1.8\end{array}$ \\
\hline $1 \times 10^{6}$ & 47.5 & $9.2 \pm 1.0$ & 22.0 & $10.5 \pm 2.1$ & 35.0 & $9.0 \pm 1.2$ & 25.5 & $\begin{array}{c}10.1 \pm \\
2.8 \\
\end{array}$ \\
\hline $1 \times 10^{7}$ & 59.5 & $5.8 \pm 1.1$ & 41.0 & $10.3 \pm 1.0$ & 45.5 & $7.5 \pm 1.5$ & 31.5 & $8.8 \pm 2.6$ \\
\hline $1 \times 10^{8}$ & 66.5 & $5.6 \pm 1.6$ & 55.5 & $9.3 \pm 1.6$ & 56.5 & $7.1 \pm 2.2$ & 50.5 & $7.5 \pm 1.9$ \\
\hline $1 \times 10^{9}$ & 88.5 & $5.1 \pm 1.9$ & 62.5 & $7.1 \pm 1.4$ & 67.5 & $6.6 \pm 2.1$ & 60.5 & $6.2 \pm 2.3$ \\
\hline
\end{tabular}

*Conc., Concentrations of conidiospores.

LT50, medial lethal time (days) \pm SE.

Table 2. Effect of entomopathogenic fungi isolates on larval duration, pupation rate and duration of $S$. littoralis treated as new hatch instars.

\begin{tabular}{|c|c|c|c|}
\hline Fungal isolates & Mean larval duration & \%Pupation & Mean pupal duration \\
(days) \pm S. E. & & & (days) \pm S. E. \\
\hline B. bassiana & $15.0 \pm 0.3^{*}$ & 48.8 & $13.2 \pm 0.1^{*}$ \\
\hline L. antillanum & $14.3 \pm 0.5^{*}$ & 45 & $12.3 \pm 0.5^{*}$ \\
\hline P. lilacinus & $15.3 \pm 0.4^{*}$ & 48.3 & $13.6 \pm 0.6^{*}$ \\
\hline M. anisopliae & $14.6 \pm 0.1^{*}$ & & $11.3 \pm 0.5^{* *}$ \\
\hline Control & $16.0 \pm 0.2$ & 100 & $14.6 \pm 0.5$ \\
\hline
\end{tabular}

*: Significant at $\mathrm{P}>0.05 \quad * *$ : highly significant at $\mathrm{P}>0.01$ 
Table 3. Effect of entomopathogenic fungi isolates on adult emergence percentage and adult longevity of $S$. littoralis treated as new hatch instars.

\begin{tabular}{|c|c|c|c|}
\hline \multirow{2}{*}{ Fungal isolates } & \multirow{2}{*}{$\begin{array}{c}\text { Adult emergence } \\
\%\end{array}$} & \multicolumn{2}{|c|}{ Mean adult longevity (days) \pm S. E. } \\
\cline { 3 - 4 } & 91.00 & $12.3 \pm 0.4^{*}$ & + \\
\hline B. bassiana & 95.00 & $9.0 \pm 1.0^{* *}$ & $11 \pm 0.28^{*}$ \\
\hline L. antillanum & 90.25 & $12.3 \pm 0.48^{*}$ & $10.3 \pm 0.57^{*}$ \\
\hline P. lilacinus & 94.40 & $8.3 \pm 1.15^{* *}$ & $13.7 \pm 0.4^{*}$ \\
\hline M. anisopliae & 100.00 & $13.6 \pm 1.15$ & $9.3 \pm 0.57^{* *}$ \\
\hline Control & &
\end{tabular}

*: Significant at $\mathrm{P}>0.05 \quad * *$ : highly significant at $\mathrm{P}>0.01$

Table 4. Effect of entomopathogenic fungi isolates on fecundity of $S$. littoralis treated as new hatch instars.

\begin{tabular}{|c|c|c|}
\hline Fungal isolates & Mean no. of eggs/female \pm S.E. & $\begin{array}{c}\text { Mean no. hatched eggs/female } \pm \\
\text { S.E. }\end{array}$ \\
\hline B. bassiana & $598 \pm 9.1^{* * *}$ & $459 \pm 3.6^{* * *}$ \\
\hline L. antillanum & $897 \pm 16.8^{* * *}$ & $545 \pm 8.5^{* * *}$ \\
\hline P. lilacinus & $623 \pm 10.2^{* * *}$ & $413 \pm 4.9^{* * *}$ \\
\hline M. anisopliae & $499 \pm 12.5^{* * *}$ & $382 \pm 4.7^{* * *}$ \\
\hline Control & $2250 \pm 60.6$ & $2203 \pm 4.04$ \\
\hline
\end{tabular}

$* * *$ : Very highly significant at $\mathrm{P}>0.001$.

\section{REFERENCES}

1. Abbott, W.S. 1925. A method for computing the effectiveness of an insecticide. J. Econ. Entomol. 18: 265- 277

2. Abd El-Kareem, S. M. 2007. Biological and histopathological studies on the effect of certain entomopathogenic microorganisms on the European corn borer, Ostrinia nubilalis Hübner (Lepidoptera: Pyralidae) M. Sc. Thesis, Fac. Sci., Ain Shams Univ.

3. Abd El-Kareem, S. M. I. 2012. Effect of some entomopathogens and insecticides against the cotton leafworm, Spodoptera littoralis (Boisduval) (Lepidoptera: Noctuidae). Ph. D. thesis, Fac. of Science, Ain Shams University, Cairo, Egypt.185 Pp.

4. Abdel-Aziz, M. M. M. 2007. Controlling of the cotton leafworm, Spodoptera littoralis (Boisd.), by using environmentally safe (nontraditional) methods. M.Sc. Thesis, Inst. Environmental Studies and Research, Ain Shams Univ. 
5. Aldebis, H. K.; E.V. Osama and C. Santiago Alvarez. 1993. Development of the male reproductive system in Spodoptera littoralis (Boisd.) (Lepidoptera: Noctuidae) treated as larvae with nuclear polyhedrosis virus (Baculovi- ridae). Boletin de Sanidad Vegetal, Plagas. 19 (1): 3 - 9.

6. Alford, D. V. 2000. Pest and disease management hand book British crop protection council, Blackwell Sci., Oxoford, 615pp.

7. Dent, D. 2000. Biological control. In: Insect Pest Management. $2^{\text {nd }}$ edition. London. CABI publishing. Ch. 6: 180-234 pp.

8. Dubois, T.; Z. Li; H. Jiafu; and E. Hajek. 2004. Efficacy of fiber bands impregnated with Beauveria brongniartii cultures against the Asian long horned beetle, Anoplophora glabripennis (Coleoptera: Cerambycidae). Biol.Control, 31: 320-328.

9. Ekesi, S.; Maniania, N.K. and Lux, S.A. 2002. Mortality in three African tephritid fly puparia and pupa caused by entomopathogenic fungi, Metarhizium anisopliae and Beauveria bassiana. Biocontrol Sci. Technol., 12(1): 7-17.

10. El-Hawary, F.M. and A.M.E. Abd El-Salam. 2009. Laboratory bioassay of some entomopathogenic fungi on Spodoptera littoralis (Boisd.) and Agrotis ipsilon (Hüfn.) larvae (Lepidoptera: Noctuidae). Egypt. Acad.J. biol. Sci., 2 (2): 1- 4.

11. El-Khateeb, S. M. and M. M. El-Sabagh. 2008. Toxicological and biological effects of Aspergillus flavus (Link) on the cotton leafworm, Spodoptera littoralis (Boisd.) (Lepidoptera: Noctuidae). Egyptian J. Agric. Res., 86 (1): 205-214.

12. Hafez, M.; F. N. Zaki; A. Moursy; and M. Sabbour. 1997. Biological effects of the entomopathogenic fungus, Beauveria bassiana on the potato tuber moth, Phthorimaea operculella (Seller). J. Pest. Sci., 70(8): 158-159.

13. Hassan, M .M. 2004. New approach for controlling the cotton leaf worm, Spodoptera littoralis. M.Sc. Thesis, Fac. Science, Mansoura Univ., Egypt.

14. Hassani, M.; G. Zimmermann and S. Vidal. 2000. Paecilomyces fumosoroseus: efficacy against the cotton pests Spodoptera littoralis (Lepidoptera: Noctuidae), Helicoverpa armigera (Lepidoptera: Noctuidae) and Aphis gossypii (Homoptera: Aphididae) and effect of temperature on germination and mycelial growth. Bulletin - OILB/ SROP.23 (2):217-221.

15. Hatem, A.E. 2006. Comparacion de los efectos de insecticidas selectivos sobre el desarralloy repoduccion de Spodoptera littoralis (Boisd.) (Lepidoptera: Noctuidae). Thesis Dextoral Universided de Cardoba.240.

16. Hicks, B. J.; A. D. Watt and D. Cosens. 2001. The potential of Beauveria bassiana (Hyphomycetes: Moniliales) as a biological control agent against the pine beauty moth, Panolis ammea (Lepidoptera: Noctuidae). Forest Ecol. \& Management, 149: $275-281$. 
17. Ismail, I. E. 1980. Physiological studies on the effect of juvenile hormone analogues upon the cotton leaf worm, Spodoptera littoralis (Boisd.). Ph. D. Thesis, Cairo Univ.

18. Kandil, M. A.; N.F. Abdel-Aziz and E.A. Sammour. 2003. Comparative toxicity of chlorofluazron and leufenuron against cotton leaf worm, Spodoptera littoralis (Boisd.). Egyp. J. Agric. Res., 2:645-661.

19. Lin, H.P., X.J. Yang, Y.B. Gao and S.G. Li. 2007. Pathogenicity of several fungal species on Spodoptera litura. Chinse J. Appl. Ecol., 18(4): 937-940.

20. Noma, T. and K. Strickler. 2000. Effects of Beauveria bassiana on Lygus hesperus (Hemiptera: Miridae) feeding and oviposition. Environ. Entomol.; 29(2): 394-402.

21. Quesada- Moraga, M. E. and A. Vey. 2004. Bassiacridin, a protein toxic for locusts secreted by the entomopathogenic fungus Beauveria bassiana. Mycol. Res. 108 (4): 441- 452.

22. Sahar, S. A. and A. M. Moharram. 2014. Biodiversity and enzymatic profile of some entomopathogenic fungi. Egypt. Acad. J. Biol. Sci., 6(1): 73-80.

23. Santiago-Alvarez, C. and E.V. Osuna. 1988. Reduction of reproductive capacity of Spodoptera littoralis males by a nuclear polyhedrosis virus (NPV). J. Invert. Pathol. 52: (1): 142- 146.

24. Vincent, C.; M.S. Goettel and G. Lazarovits. 2007. Biological control, a global perspective. CABI publishing. Oxfordshire, United Kingdom, 2007. 


\title{
فعالية عزلات فطرية محلية ممرضة للحشرات ودراسات بيولوجية علي دودة ورق القطن
}

\author{
سحر سيل علي مروة محمد محمود الصباغ$$
\text { معهل بحوث وقاية النباتات - مركز البحوث الزراعية - دقي - جيزة - مصر. }
$$ \\ تـم عمـل إختبـار مقارنة بين اربـع عزلات فطرية ممرضة للحشرات

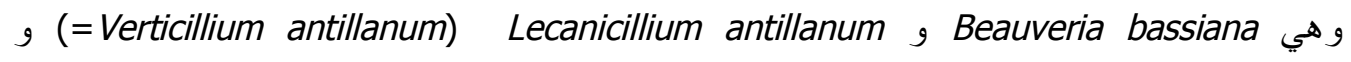 \\ Metarhizium anisopliaeg Paecilomyces lilacinus \\ الحيوية بمعهد بحوث وقاية النباتات وذللك لمعرفة شدة إلاصابة بإستخدام الجر اثثم الكونيدية بتركيز ات



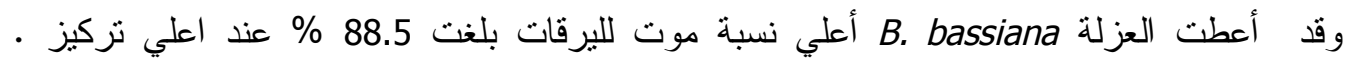

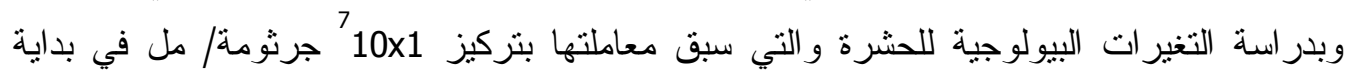

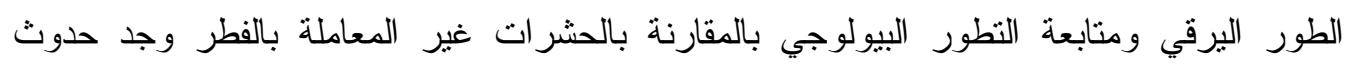

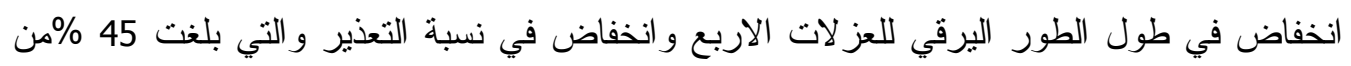

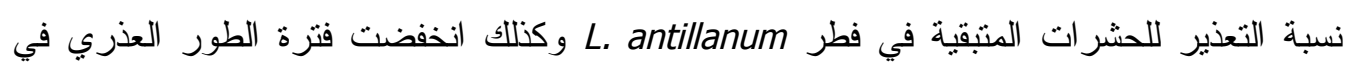 \\ جميع المعاملات بالمقارنة بالحشرات غير المعاملة ثم انخفضت نسبة ظهور الفراشات في جميع \\ المعاملات وقصرت فترة بقاء الفراثات الاناث و الذكور علي حد سواء في جميع المعاملات و اخيرا \\ حدث خفض كبير في اعداد البيض التي وضعتها الفر اشات في جميع المعاملات وكذلك خفض كبير \\ في منوسط اعداد الفقس •
}

